\title{
Difficult airways for advanced mask design
}

\author{
Hsin-Chang Lin ${ }^{1,2,3}$, Chih-Cheng Lu ${ }^{2,4}$ \\ ${ }^{1}$ Department of Internal Medicine, Mackay Memorial Hospital, Taipei, Taiwan; ${ }^{2}$ Graduate Institute of Mechanical and Electrical Engineering, \\ National Taipei University of Technology, Taipei, Taiwan; ${ }^{3}$ Mackay Medicine, Nursing and Management College, Taipei, Taiwan; ${ }^{4}$ Department of \\ Intelligent Automation Engineering, National Taipei University of Technology, Taipei, Taiwan \\ Correspondence to: Chih-Cheng Lu. Department of Intelligent Automation Engineering, National Taipei University of Technology, Taipei, Taiwan. \\ Email: cclu23@ntut.edu.tw.
}

Received: 06 January 2019; Accepted: 14 November 2019; Published: 31 December 2019.

doi: $10.21037 /$ ht.2019.11.04

View this article at: http://dx.doi.org/10.21037/ht.2019.11.04

We read the editorial by Shih-Yi Lee et al. on "Prospective view for mask design" with a great interest (1). In the article, the authors have proposed a new mask design for difficult mask ventilation (DMV). We would like to suggest them take the risk factors of difficult intubation (DI) into consideration into the design of novel masks, because both DMV and DI possibly cause difficult airways, though the risk factors between DMV and DI are different in some ways (2-5).

Both mask ventilation and trachea intubation are used to secure the airway of patients, and the DMV and DI risk their lives, especially in critical condition during resuscitation. DMV increases the risk of procedure-related eye and eyelid injury, nerve injury, gastric insufflation, aspiration, vomiting, and over-inflation; on the other hand, DI may cause dental injuries, esophageal trauma, laryngeal damage, and hoarseness, which physicians need to take care of when encountering DI (6).

Airway management maneuvers and techniques, face mask adjuncts, intubating laryngeal mask airway, nasal mask ventilation, and tracheostomy are current ways to resolve the problems caused by DMV $(1,7)$. Advanced techniques such as fiberoptic intubation with/without positive pressure ventilation have been suggested for DI $(8,9)$. A new mask should be designed to resolve the problems caused by DMV and DI that both results in difficult airways.

\section{Acknowledgments}

Funding: None.

\section{Footnote}

Provenance and Peer Review: This article was commissioned by the editorial office, Health Technology. This article did not undergo external peer review.

Conflicts of Interest: The authors have no conflicts of interest to declare.

Ethical Statement: The authors are accountable for all aspects of the work in ensuring that questions related to the accuracy or integrity of any part of the work are appropriately investigated and resolved.

Open Access Statement: This is an Open Access article distributed in accordance with the Creative Commons Attribution-NonCommercial-NoDerivs 4.0 International License (CC BY-NC-ND 4.0), which permits the noncommercial replication and distribution of the article with the strict proviso that no changes or edits are made and the original work is properly cited (including links to both the formal publication through the relevant DOI and the license). See: https://creativecommons.org/licenses/by-nc-nd/4.0/.

\section{References}

1. Lee SY, Kuo CY, Wei DH, et al. Prospective view for mask design. Health Technol 2017;1:3.

2. Langeron $\mathrm{O}$, Masso E, Huraux $\mathrm{C}$, et al. Prediction of difficult mask ventilation. Anesthesiology 2000;92:1229-36 
3. Cho J, Cho YS, You JS, et al. Current status of emergency airway management for elderly patients in Korea: Multicentre study using the Korean Emergency Airway Management Registry. Emerg Med Australas 2013;25:439-44.

4. Lee SY, Shih SC, Leu YS, et al. Implications of age-related changes in anatomy for geriatric-focused difficult airways. Int J Gerontol 2017;11:130-133.

5. Lee SY, Chien DK, Huang MY, et al. Patient-specific factors associated with difficult mask ventilation in the emergency department. Int J Gerontol 2017;11:263-6.

6. Rose DK, Cohen MM. The airway: problems

doi: 10.21037/ht.2019.11.04

Cite this article as: Lin HC, Lu CC. Difficult airways for advanced mask design. Health Technol 2019;3:12. and predictions in 18,500 patients. Can J Anaesth 1994;41:372-83.

7. Takaishi K, Kawahito S, Tomioka S, et al. Cuffed oropharyngeal airway for difficult airway management. Anesth Prog 2014;61:107-10.

8. Collins SR, Blank RS. Fiberoptic intubation: an overview and update. Respir Care 2014;59:865-78; discussion 878-80.

9. Aoyama K, Yasunaga E, Takenaka I, et al. Positive pressure ventilation during fibreoptic intubation: comparison of the laryngeal mask airway, intubating laryngeal mask and endoscopy mask techniques. Br J Anaesth 2002;88:246-54. 